\title{
Evaluation of Cassava (Manihot esculenta Crantz) Productivity in Relation to Termite Attacks in Rural Area in Tivaouane (Senegal)
}

\author{
Arfang Mafoudji Sonko ${ }^{1,2}$, Dienaba Sall ${ }^{3}$, Mouhamadou Moustapha Ndiaye ${ }^{1} \&$ Abdoulaye Baïla Ndiaye $^{1}$ \\ ${ }^{1}$ Laboratory of Terrestrial Invertebrate Zoology, Institut Fondamental d'Afrique Noire Cheikh A. Diop, Cheikh \\ Anta Diop University, Dakar, Senegal \\ ${ }^{2}$ Department of Plant Biology, Faculty of Science and Technology, University Cheikh Anta Diop of Dakar, \\ Dakar-Fann, Senegal \\ ${ }^{3}$ National Laboratory on Crop Production Research, Senegalese Agricultural Research Institute, Dakar, Senegal \\ Correspondence: Arfang Mafoudji Sonko, Laboratory of Terrestrial Invertebrate Zoology, Institut Fondamental \\ d'Afrique Noire Cheikh A. Diop (IFAN Ch. Anta Diop), Cheikh Anta Diop University (UCAD), B.P. 206, Dakar, \\ Senegal. Tel: 221-77-238-4455. E-mail: arfang89@gmail.com
}

Received: February 12, 2021

Accepted: April 5, $2021 \quad$ Online Published: May 15, 2021

doi:10.5539/jas.v13n6p82

URL: https://doi.org/10.5539/jas.v13n6p82

\begin{abstract}
In Senegal, the cassava harvest, produced mainly in the department of Tivaouane (Thies), is $7.5 \mathrm{t} / \mathrm{ha}$ on average for a potential of $40 \mathrm{t} / \mathrm{ha}$. The main variety produced in Tivaouane is Soya. The objective of this study is to evaluate the productivity of the soya variety farmed in Tivaouane in relation to termite damage. Specifically, it is intended to i) evaluate losses caused by termites and missing plants ii) evaluate the average number of tubers per plant, the average weight of a tuber and iii) calculate the yield of cassava production of the Soya variety farmed in Tivaouane. The methodology is based on sampling in order to evaluate parameters such as losses due to termites and missing plants, evaluation of the number of tubers per plant, the average weight of a tuber and the productivity of this variety of cassava. The average loss due to termite attack on dead feet is $1.2 \mathrm{t} / \mathrm{ha}$ and the loss due to missing feet is estimated at $3.4 \mathrm{t} / \mathrm{ha}$. The average number of tubers per stand is 2.8 with an average weight of $1.1 \mathrm{~kg}$ per tuber. The theoretical yield obtained is $11 \mathrm{t} / \mathrm{ha}$. The low average number of tubers is related to the variety, the quality of the soil and the crop conditions. However, the productivity of this variety of cassava cropped in Tivaouane is still low considering the potential of Senegal in terms of annual cassava production. An improvement in crop conditions, such as the way cuttings are planted, would be an advantage in increasing the productivity of the Soya variety.
\end{abstract}

Keyswords: agricultural productivity, Soya variety, cassava, losses, termites, Tivaouane

\section{Introduction:}

Cassava, (Manihot esculenta Crantz 1766), is the main food of more than 800 million people in tropical areas 500 million of them in Africa (Vernier et al., 2018). Classified as the fourth largest crop in the world after rice, wheat and corn, cassava remains an important food, especially in West Africa where a strategic food to fight against malnutrition main food crop in many countries (SCA, 2013). Indeed, in the Democratic Republic of the Congo, tubers provide more than $60 \%$ of the calories needed for two thirds of the population (Mahungu et al., 2014). The leaves, rich in protein (25\%), iron, calcium, vitamin $A$ and $C$, are also used as a vegetable, condiment or forage (Cacai et al., 2012; Diallo et al., 2013; FAO, 2013). Exclusively product by small producers, cassava is often produced in marginal areas with poor soils and uncertain rainfall and contributes to the fight against food insecurity (FAO, 2013). In 2017, the world production of plants and tubers reached 845 million tons of fresh material, of which $32 \%$ was represented by cassava (Vernier et al., 2018). Nigeria, the greatest world producer, grows an average of 59,475,202 t/year of cassava representing 57\% of world production (FAOSTAT, 2020). In Senegal, the country's production potential is estimated at 1000,000 tonnes per year (SCA, 2013). According to DAPSA (2017), cassava area increased from 20868 hectares to 30813 hectares from 2013 to 2015 with an average production of about $8 \mathrm{t} / \mathrm{ha}$. The department of Tivaouane (Thies region) being the granary of cassava production in Senegal provides 55\% of the national production (SCA, 2013). In Tivaouane, cassava production is still characterized by low yields $(7.5 \mathrm{t} / \mathrm{ha})$ due to a number of constraints and the agro-ecological conditions of the area. Cassava production is limited by pests and diseases (Zeyimo et al., 2019). As a result, yields of cassava 
grown in Tivaouane (7.5 t/ha) are low compared to Nioro (22.5 t/ha) according to Agriculture Statistics Analysis and Forecasting Directorate (DAPSA) data (2017). These weaknesses would be partly related to abiotic, anthropic, etc. factors that cause some missing plants during production and biotic causes, such as pest pressure, including termites that cause a lot of damage. However, there are five species of termites distributed among fungis growers (Odontotermes erraticus, Microtermes lepidus and Macrotermes subhyalinus) and lignivores (Psammotermes hybostoma and Microcerotermes sp.) have been identified on cassava (Sonko et al., 2019) to be a pest of the cassava plantations in Tivaouane Indeed, termite attacks are made from the outside under earth veneers or from the inside with or without earth filling of the gnawed parts. They lead to reduced growth or death of infested cassava cuttings and young plants.

These species are responsible of attacks and damage on cassava, whose severity and incidence are respectively of the order of $37.5 \%$ and $48 \%$ (Sonko et al., 2019). Thus, would be responsible for the losses on cuttings, plants and yield reductions recorded in Tivaouane. They can cause very serious damage and negatively affect the profitability and performance of the varieties grown in Tivaouane. The objective of this study is to analyze the productivity of this Soya variety farmed in Tivaouane in relation to termite damage. It specifically aims to i) evaluate losses due to termites and missing plants; ii) evaluate the average number of tubers per plant, the average weight of a tuber; and iii) calculate the yield of cassava production of the Soya variety produced in Tivaouane.

\section{Methods}

\subsection{Study Environment}

The study was conducted in Tivaouane department (Thies-Senegal). Located $92 \mathrm{~km}$ from Dakar the Senegalese capital, the department of Tivaouane covers an area of $3221 \mathrm{~km}^{2}$, it is larger than the department of Thies, 1873 $\mathrm{km}^{2}$ and the department of Mbour, $1607 \mathrm{~km}^{2}$. According to ANSD/SRSD (2011), at the Tivaouane department level, $70 \%$ of the soils are sandy dune (dior dune soil), $15 \%$ clay-sandy (dior deck), $10 \%$ clay-humic (deck) and $5 \%$ hydromorphic.

The climate of Tivaouane is characterized by the existence of two seasons: the dry season and the rainy season. The long dry season runs from October to July. The rainy season runs from July to October. The region enjoys a mild climate with an average annual temperature of $32{ }^{\circ} \mathrm{C}$ (ANSD/SRSD, 2017). The lowest temperatures are recorded between January and February and the highest $\left(35^{\circ} \mathrm{C}\right)$ between March and October (ANSD/SRSD, 2017).

The study has been conducted in Tivaouane in cassava farms under 5 months of age (figure 1), regarding the impact of termites on young cassava plants and on harvest ready plots (over 12 months) for the evaluation of productivity and yield. 


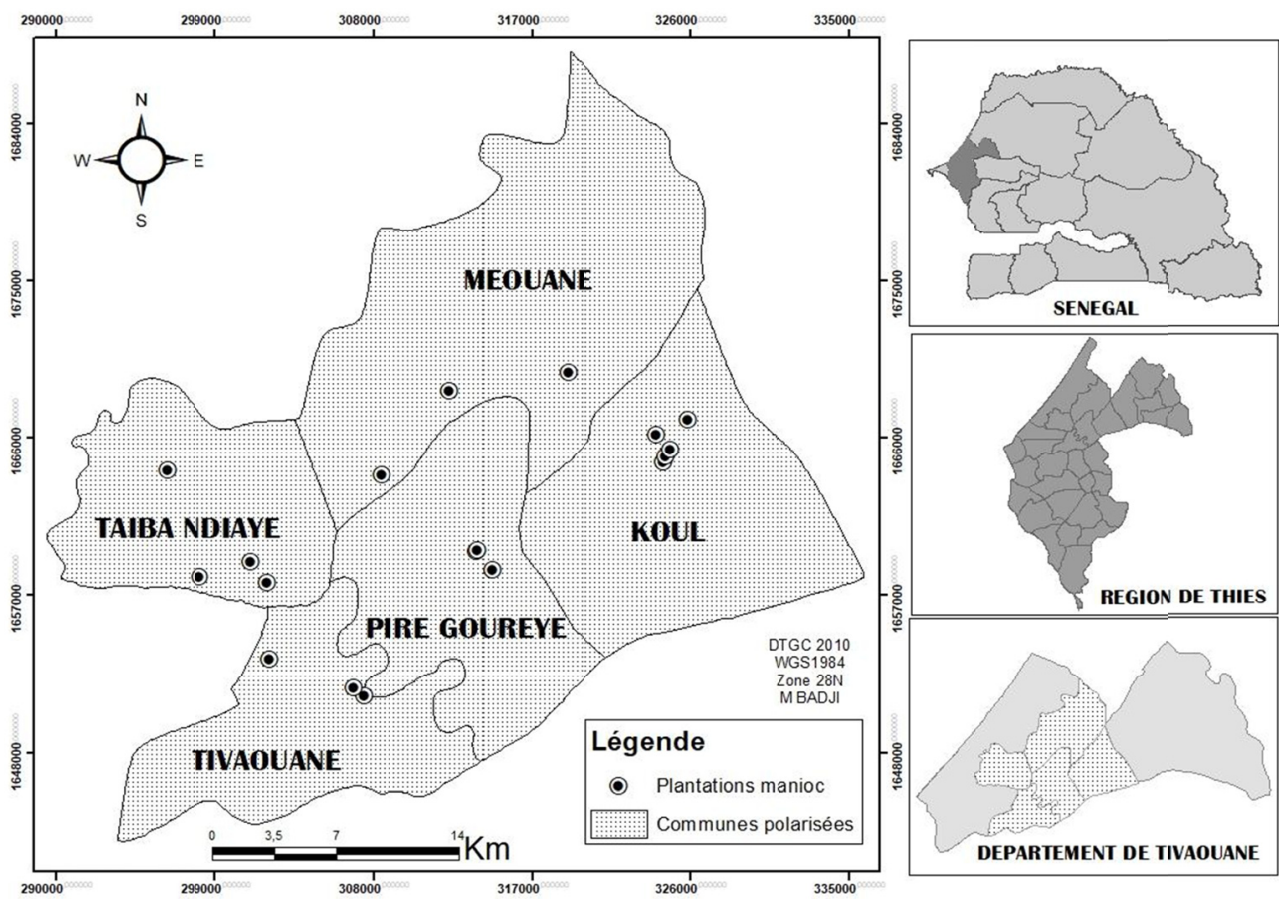

Figure 1. Location of sites and sampling stations (plots) for termites in the department of Tivaouane

\subsection{Sampling Methodology}

Sampling of seedlings has been conducted in cassava plantations situated in: Tivaouane (1), Taïba Ndiaye (3) and Koul (5). Nine plantations have been visited. The sampling unit is a 1 ha plot. In each plot, 3 squares of 100 $\mathrm{m} 2$ each have been measured diagonally with a decameter. In each plantation, observations have been taken on the condition of the plant and the termite attack marks. Missing plants have been identified according to the arrangement of the sideline and spacing.

\subsection{Evaluation of the Productivity of the Soya Variety Grown in Tivaouane}

This part has been realized at harvest time around Pire Goureye in 6 plots of cassava of the Soya variety (the most cultivated variety in Tivaouane). The plots studied have been taken randomly during the cassava harvest periods, which are defined according to the needs of the producer from the 14th month of the production cycle. In each plot, the number of plants to be dug up depends on the farmer's instructions. A total of 505 feet have been harvested.

The productivity of a cassava plant corresponds here to the average weight of a tuber and the average number of tubers produced by the plant. The theoretical yield (RT) corresponds here to the cassava production per hectare, considering that all the cuttings planted at the start, with $1 \mathrm{~m}$ spacing, have reached maturity.

To determine productivity, at harvest time, the number of tubers in each plant dug up is counted and the weight of the tubers in the plant is weighed with a scale.

The data collected and entered with Excel enabled to evaluate the average weight of a tuber and the average number of tubers in each plant according to the following formulas:

\subsubsection{Average Tuber Weight of a Cassava Plant (PMT)}

For the calculations, the averaging formulas used by Dajoz (1971) were adapted according to the study.

The average tuber weight of a cassava plant is calculated by the following formula:

$$
\mathrm{PMT}=\frac{\mathrm{PTT}}{\mathrm{NPO}}
$$

where, PMT: Average weight of the tubers of a cassava plant; PTT: Total weight of tubers in the feet observed; NPO: Number of feet observed.

\subsubsection{Average Number of Tubers per Stand of Cassava (NMT)}

The average number of tubers per cassava plant is obtained by the following formula: 


$$
\mathrm{NMT}=\frac{\mathrm{NTTPO}}{\mathrm{NPO}}
$$

where, NMT: Average number of tubers per plant; NTTPO: Total number of tubers of all the plants observed; NPO: Total number of feet observed.

Software R version 3.6.3 (2020-02-29) was used to compare the weight of tubers between the different farms visited.

The NMT and PMT are then used to evaluate the theoretical performance (RT).

\subsection{Evaluation of Yield Losses}

\subsubsection{Losses due to Dead Feet Attacked by Termites (PPMo)}

These are cassava plants or cuttings found dead on the spot as a result of termite attacks. Observations made on these plants at the time of sampling show that they died as a result of termite attacks. The termite attack marks are visible on observation. These losses are evaluated by the formula:

$$
\mathrm{PPMo}=\mathrm{PMT} \times \mathrm{NPMO}
$$

where, PPMo: Losses due to observed dead feet; PMT: Average tuber weight per plant; NPMO: Number of dead feet observed.

\subsubsection{Losses due to Missing Feet (PPM)}

In each plot, depending on the disposal of the feet at transplanting time, some of them disappear sometime after implantation. These lacks of plants are due to biotic causes (termite action, anthropic) or abiotic causes. Losses caused by missing plants observed during termite sampling are determined by the formula:

$$
\mathrm{PPM}=\mathrm{PMT} \times \mathrm{NPM}
$$

where, PPM: Losses due to missing feet; PMT: Average weight of tubers in a plant; NPM: Number of missing feet.

\subsection{Yield of Cassava Tuber Production}

Considering all the cuttings planted at the beginning with a spacing of $1 \mathrm{~m}$, there should be 10000 cassava plants in 1 hectare. Thus, the theoretical yield of cassava production is obtained with the following formula:

$$
\mathrm{RT}=\mathrm{PMT} \times 10000
$$

where, The number 10,000 represents the total number of cassava root planted on 1 ha with a $1 \mathrm{~m}$ spacing.

The actual production yield is defined here as the difference between the theoretical yield and losses (due to termites and missing plants).

\section{Results}

\subsection{Assessment of Losses Related to Missing and Dead Feet Attacked by Termites}

Losses related to missing feet and attacked dead feet are evaluated and presented in Table 1. For all sites combined, losses from missing feet observed during sampling are estimated at $3.406 \mathrm{t} / \mathrm{ha}$ and dead feet attacked by termites at $1.208 \mathrm{t} / \mathrm{ha}$.

At the Koul site, the losses ( $t / h a)$ related to missing feet are $3.534 \mathrm{t} / \mathrm{ha}$ and those related to dead feet attacked by termites are $1.657 \mathrm{t} / \mathrm{ha}$.

At Taïba Ndiaye, the losses ( $t / h a)$ related to missing feet totaled $2.469 \mathrm{t} / \mathrm{ha}$ and those related to dead feet attacked by termites are $1.014 \mathrm{t} / \mathrm{ha}$.

In Tivaouane, the losses in cassava production due to missing and dead plants attacked by termites are respectively estimated at $4.216 \mathrm{t} / \mathrm{ha}$ and $0.953 \mathrm{t} / \mathrm{ha}$. 
Table 1. Average number per hectare of missing and dead feet attacked by termites per site

\begin{tabular}{llll}
\hline \multirow{2}{*}{ Site } & Station & \multicolumn{2}{c}{ Average number of feet of stations } \\
\cline { 2 - 4 } Taïba Ndiaye & Taïba Ndiaye & 4533.3 & Mead feet attacked \\
\hline & Mbayenne & 633.3 & 33.3 \\
& Thialé-Kholane & 1566.7 & 1000 \\
& Average & $\mathbf{2 2 4 4 . 4}$ & 1733.3 \\
& Ndiakhalam & 1600 & $\mathbf{9 2 2 . 2}$ \\
\hline \multirow{3}{*}{ Koul } & Kilou Fall 1 & 2300 & 766.7 \\
& Kilou Fall 2 & 4266.7 & 500 \\
& Gade Koul & 3566.7 & 1933.3 \\
& Sakh & 4333.3 & 1566.7 \\
& Average & $\mathbf{3 2 1 3 . 3}$ & 2766.7 \\
& Sinthiou Pire & 3833.3 & $\mathbf{1 5 0 6 . 7}$ \\
\hline
\end{tabular}

\subsection{Average Number of Tubers per Plant}

The average number of tubers per stand of cassava (NMT) varies from 1.4 (Pire station) to 3.7 (Ndeukou station 1). The average of all stations combined is 2.8 tubers per stand (Table 2). The p-value is significant (p 2.2-16), so there are significant differences in the average number of tubers according to the sites with the Kruskal-Wallis test.

Table 2. Average number of tubers per plant

\begin{tabular}{llll}
\hline Site & Plot & Observed cassava plant & NMT \\
\hline Pire & 1 & 28 & 1.4 \\
Moussa Mbaye & 1 & 169 & 2.2 \\
Mborine & 1 & 42 & 3.1 \\
Mborine & 2 & 130 & 3 \\
Ndeukou & 1 & 47 & 3.7 \\
Ndeukou & 2 & 89 & 3.3 \\
\hline Average & 2.8 & & \\
Df & 3 & & \\
P & $2.2^{-16}$ & & \\
\hline
\end{tabular}

\subsection{Average Weight of Tubers per Plant}

The average weight of cassava tubers per plant (PMT) also varies from one station to another. The lowest PMT $(0.5 \mathrm{~kg})$ is observed at the Pire station and the highest $(1.7 \mathrm{~kg})$ at Mborine station 1 (Table 3) with p-value = 4.149-9. The PMT, all stations combined, is $1.1 \mathrm{Kg} /$ tuber. The $\mathrm{p}$-value is significant $(\mathrm{p}=4.1-9)$, so there are significant differences in average tuber weight between sites with Kruskal-Wallis test. 
Table 3. Average weight of tubers per plant

\begin{tabular}{llll}
\hline Site & Plot & Observed cassava plant & PMT $\mathbf{( k g )}$ \\
\hline Pire & 1 & 28 & 0.5 \\
Moussa Mbaye & 1 & 169 & 0.9 \\
Mborine & 1 & 42 & 1.7 \\
Mborine & 2 & 130 & 1 \\
Ndeukou & 1 & 47 & 1.2 \\
Ndeukou & 2 & 89 & 1.1 \\
\hline Average & 1.1 & & \\
Df & 3 & & \\
P & $4.149^{-9}$. & & \\
\hline
\end{tabular}

\subsection{Yield of Cassava Production in Tivaouane}

The average theoretical yield is $11 \mathrm{t} / \mathrm{ha}$ (Table 4). From one station to another, it varies from 5 (Pire station) to 17 $\mathrm{t} / \mathrm{ha}$ (Mborine station 1). Considering the losses recorded, the actual yield obtained is $5.8 \mathrm{t} / \mathrm{ha}$.

Table 4. Yield of cassava production in Tivaouane

\begin{tabular}{llll}
\hline Site & Plot & Observed cassava plant & RT (t/ha) \\
\hline Pire & 1 & 28 & 5 \\
Moussa Mbaye & 1 & 169 & 9 \\
Mborine & 1 & 42 & 17 \\
Mborine & 2 & 130 & 10 \\
Ndeukou & 1 & 47 & 12 \\
Ndeukou & 2 & 89 & 11 \\
\hdashline Average & 11 & & \\
\hline
\end{tabular}

\section{Discussion}

Information obtained on cassava productivity in Tivaouane revealed that it is low. The planting density of cassava plants is $10,000 \mathrm{plants} / \mathrm{ha}$ and the average number of tubers produced per plant is 2.8 . The significant difference observed at the site level in terms of average number of tubers would be related to the cropping practices and the degree of termite attack. Indeed, according to Raffaillac and Second (1997), the number of roots that develop into tubers varies according to varieties, environmental conditions but also cultivation techniques. According to these authors, in a total of 24 roots, 18 will be transformed into tubers for a planting density of 6000 plants/ha and only 6 will give tubers if the density is 15000 plants/ha. The average weight of a tuber obtained in this study is $1.1 \mathrm{~kg}$ and corresponds to the interval of the average weight given by Favier (1977) in which the weight of a tuber root is between $200 \mathrm{~g}$ and $3 \mathrm{~kg}$. This difference in tuber weight would be closely related to the consequences of termite attacks but also to the number of tuber roots. The losses on the Soya variety obtained in this study, related to termites $(1.2 \mathrm{t} / \mathrm{ha})$ and missing plants $(3.4 \mathrm{t} / \mathrm{ha})$, could explain the low national cassava yields. These results confirm those of Raffaillac and Second (1997) on parameters that could influence root tuberization. Apart from these parameters, the actions of termites on cassava also contribute strongly to the reduction in the number of tuberized roots. In West Africa, termites have been reported as a pest of cassava in northern Ghana (Maayiem et al., 2012). In Malawi, southern Africa, Munthali et al. (1999) reported termite attacks on cassava plantations. Some termite species usually attack the stems from the inside starting from the roots and/or crown (Pearce, 1997) causing severe damage. These losses may be increasing as other termite damage parameters such as the impact of attacks on the number of tuberized roots had not been considered in this study. Losses related to the missing feet would be closely linked to termites. These plants disappear following termite attacks that transform the implanted cutting into sand, creating an empty space from which the missing plants disappear. Losses due to these missing feet not only impact production and yield, but also cause economic losses. Considering the theoretical yield obtained, which is $11 \mathrm{t} / \mathrm{ha}$, the actual yield obtained at Tivaouane is estimated at $5.8 \mathrm{t} / \mathrm{ha}$. The yield obtained is low because in classical conditions, the yield per hectare varies between 8 and 15 t/ha (Kouakou et al., 2015). This yield is quite similar to that obtained by DAPSA in 2017 during the evaluation of the 2014-2015 crop year in the department of Tivaouane. During this 
crop year, national production in terms of tubers was 254,983 tons and a national yield of 8.2 t/ha compared to a potential of 1,000,000 tons per year (DAPSA, 2017).

\section{Conclusion}

At the end of this study, on the evaluation of yield losses and productivity of the variety Soya of cassava cultivated in Tivaouane, it was retained that the yield losses related to missing plants amounted to $4.216 \mathrm{t} / \mathrm{ha}$ and that of termite losses $0.953 \mathrm{t} / \mathrm{ha}$. In addition, some of the losses related to missing plants are caused by termites. The productivity of a cassava plant of this Soya variety is very low, averaging 2.8 tubers with an average weight of $1.1 \mathrm{~kg}$ per tuber. With a theoretical yield of $11 \mathrm{t} / \mathrm{ha}$ and an effective yield of $5.8 \mathrm{t} / \mathrm{ha}$ taking into account losses, the Soya variety has a low productivity from an agronomic point of view. These results show that the productivity of this cassava variety produced in Tivaouane remains low, however, considering Senegal's potential in terms of annual cassava production.

\section{References}

ANSD (Agence Nationale de la Statistique et de la Démographie). (2017). Situation économique et sociale régionale en 2014 (p. 157).

ANSD/SRSD (Agence Nationale de la Statistique et de la Demographie/Service Regional de la Statistique et de la Demographie de Thiès). (2011). Situation économique et sociale régionale 2010 (p. 134).

Cacai, G. H. T., Ahanhanzo, C., Dangou, J. S., Houedjissin, S. S., \& Agbangla, C. (2012). Effets de différentes combinaisons hormonales sur l'organogenèse in vitro de quelques cultivars locaux et variétés améliorées de Manihot esculenta Crantz (manioc-Euphorbiaceae) cultivées au Bénin. International Journal of Biological and Chemical Science, 6(4), 1593-1607. https://doi.org/10.4314/ijbcs.v6i4.19

Dajoz, R. (1971). Précis d'écologie (p. 434). Dunod, Paris.

DAPSA (Direction de l'Analyse, de la Prévision et des Statistiques Agricoles). (2017). Résultats définitifs de la campagne agricole 2014-2015.

FAO. (2013). Produire plus avec moins: Le manioc. Guide pour une intensification durable de la production (p. 128).

FAOSTAT. (2020). Statistiques production manioc Afrique de l'ouest. Retrieved December 14, 2020, from http://www.fao.org/faostat/fr

Favier, J. C. (1977). Valeur alimentaire de deux aliments de base africains: Le manioc et le sorgho (Travaux et Document $\mathrm{N}^{\circ} 67$, p. 118). ORSTOM, Paris.

Kouakou, J., Nanga, S., Plagne-Ismail, C., Aman, M. P., \& Ognakossan, K. E. (2015). Production et transformation du manioc (p. 40). La Collection Pro-Agro, Yaoundé-Cameroun.

Maayiem, D., Bernard, B. N., \& Irunuoh, A. O. (2012). Indigenous knowledge of termite control: A case study of five farming communities in Gushegu District of Northern Ghana. Journal of Entomology and Nematology, 4(6), 58-64. https://doi.org/10.5897/JEN12.020

Mahungu, N. M., Tata Hangy, K. W., Bidiaka, S. M., \& Frangoie, A. (2014). Multiplication de materiel de plantation de manioc et gestion des maladies et ravageurs. Manuel de formation destiné aux agents de terrain (p. 44). Institut International d'Agriculture Tropicale.

Munthali, D. C., Logan, J. W. M, Wood, T. G, \& Nyirenda, G. K. C. (1999). Termite distribution and damage to crops on smallholder farms in southern Malawi. International Journal of Tropical Insect Science, 19(1), 43-49. https://doi.org/10.1017/S174275840001657X

Pearce, M. J. (1997). Termites. Biology and pest management (p. 172). CAB International: Wallingford.

Raffaillac, J. P., \& Second, G. (1997). Le manioc. In A. Charrier et al. (Eds.), L'amélioration des plantes tropicales (pp. 429-455). Montpellier, France, CIRAD-ORSTOM.

SCA (Stratégie de Croissance Accélérée). (2013). Étude sur l'organisation et la structuration de filières agricoles au Sénégal en des chaînes de valeur performantes dans le cadre de la Grappe Agriculture et Agro-industrie (p. 20). Chaîne de valeur manioc, rapport SCA.

Sonko, A. M., Sall, D., \& Ndiaye, A. B. (2019). Les termites (Termitoidae Latreille 1802) ravageurs du manioc (Manihot esculenta Crantz 1766) dans la zone de Tivaouane (Sénégal). International Journal of Biological and Chemical Sciicence, 13(4), 2005-2020. https://doi.org/10.4314/ijbcs.v13i4.8

Vernier, P. N'Zué, B., \& Zakhia-Rozis, N. (2018). Le manioc, entre culture alimentaire et filière agro-industrielle. 
Agricultures tropicales en poche (p. 232). Editions Quae. https://doi.org/10.35690/978-2-7592-2708-2

Zeyimo, B., Boykin, L. M., Mahungu, N., Ndofula, M., Magole, M., Nduandele, N., ... Kanana, T. (2019). First report and preliminary evaluation of cassava root necrosis in angola. International Journal of Agriculture, Environment and Bioresearch, 4(3), 37-46. http://doi.org/10.35410/IJAEB.2019.3746

\section{Copyrights}

Copyright for this article is retained by the author(s), with first publication rights granted to the journal.

This is an open-access article distributed under the terms and conditions of the Creative Commons Attribution license (http://creativecommons.org/licenses/by/4.0/). 